\title{
MENINGKATKAN KOSAKATA BAHASA INGGRIS MELALUI BERMAIN GAMBAR PADA KELOMPOK BELAJAR ANAK SD DI KELURAHAN KATOBENGKE
}

\author{
Nur Dahniar \\ Prodi Pendidikan Guru Sekolah Dasar, Fakultas Keguruan dan Ilmu Pendidikan \\ Universitas Muhammadiyah Buton, Jl. Betoambari No. 36 Baubau. \\ E-mail: nurdahiar.powerbbuttonqueen@gmail.com
}

\begin{abstract}
Abstrak
Penelitian ini bertujuan untuk meningkatan kosakata bahasa Inggris melalui bermain gambar kelompok belajar anak SD di Kelurahan Katobengke. Penelitian ini merupakan penelitian tindakan kelas kolaboratif. Subjek dalam penelitian ini adalah anak usia 7-11 tahun yang tergabung dalam Kelompok belajar dan berjumlah 20 anak. Metode yang digunakan untuk pengumpulan data yaitu observasi dan dokumentasi. Analisis data yang digunakan dalam penelitian ini yaitu deskriptif kualitatif dan kuantitatif. Hasil penelitian menunjukkan bahwa melalui bermain gambar pembelajaran bahasa Inggris mudah diserap oleh anak. Berdasarkan data hasil penelitian tindakan kelas tersebut maka dapat disimpulkan bahwa melalui bermain gambar dapat meningkatkan kosakata bahasa Inggris anak kelompok belajar anak SD di Kelurahan Katobengke terbukti dan dapat diterima kebenarannya.
\end{abstract}

Kata kunci: kosakata bahasa Inggris, bermain gambar, anak kelompok kelompok belajar anak SD

\begin{abstract}
This study aims to improve English vocabulary through playing pictures of elementary school children learning groups in Katobengke. This research is collaborative classroom action research. The subjects in this study were children aged 7-11 years who joined the study group and numbered 20 children. The method used for data collection is observation and documentation. Analysis of the data used in this study is descriptive qualitative and quantitative. The results of the study show that through playing English learning images are easily absorbed by children. Based on the data from the class action research, it can be concluded that through playing images can increase the English vocabulary of the children of the study group elementary school children in the Katobengke Village proven and acceptable truth.
\end{abstract}

Keywords: English vocabulary, playing pictures, elementary school children learning group children 


\section{SANG PENCERAH}

Volume 4, Nomor 2, Agustus 2018, Hlm. 39-50

Nur Dahniar: Meningkatkan Kosakata Bahasa Inggris ...

\section{Pendahuluan}

Pendidikan Anak sekolah dasar merupakan pendidikan yang diselenggarakan untuk mengembangkan pribadi, pengetahuan, dan keterampilan yang melandasi pendidikan dasar serta mengembangkan diri secara utuh sesuai dengan asas pendidikan sedini mungkin dan seumur hidup (Suyanto, 2005: 45). Aspek yang dikembangkan dalam Pendidikan Anak sekolah dasar adalah aspek pengembangan perilaku dengan pembiasaan yang meliputi sosial, emosi, kemandirian, nilai- nilai moral dan agama serta pengembangan kemampuan dasar yang meliputi pengembangan fisik motorik, kognitif, dan bahasa (Arikunto, 2007: 11). Bahasa merupakan alat komunikasi yang amat penting. Manusia dalam kehidupannya, tidak bisa terlepas dari bahasa sebagai alat komunikasinya. Bahasa akan mempermudah manusia dalam bergaul, berkomunikasi, dan menyesuaikan dirinya dengan lingkungan. Dengan demikian jelaslah bahwa bahasa mempunyai peran yang amat penting bagi manusia (Suhartono, 2005: 12).

Bahasa anak berkembang sejak tangisan pertama sampai anak bertutur kata. Masa perkembangan bahasa anak dibagi dalam dua periode, yaitu periode Pre Linguistik (0-1 tahun) dan periode Linguistik (1-5 tahun). Pada masa Pre Linguistik anak mengeluarkan suara-suara dan ocehan-ocehan yang belum bisa dimengerti dan dipahami. Sedangkan pada periode Linguistik anak mulai berbicara satu atau dua kata yang sudah bisa dimengerti dan dipahami. Apabila pada periode Linguistik ini anak banyak diberi stimulasi bahasa, maka perkembangan bahasa anak akan pesat dan optimal (Tadkiroatun Musfiroh, 2005: 3). Tadzkiroatun Musfiroh (2005: 6) mengatakan bahwa perkembangan bahasa anak meliputi perkembangan fonologis (yakni mengenal dan memproduksi suara), perkembangan kosakata, perkembangan semantik dan makna kata, perkembangan sintaksis atau penyusunan kalimat, dan perkembangan pragmatik atau penggunaan bahasa untuk keperluan komunikasi sesuai dengan norma konvesi. Ada dua tahapan dalam pemerolehan bahasa anak usia dini yaitu pemerolehan bahasa pertama dan pemerolehan bahasa kedua (Sanjaya, 2009: 37).

Pemerolehan bahasa pertama adalah bahasa pertama yang diperoleh dan dipahami anak dari kehidupan dan berkomunikasi di lingkungannya. Bahasa ibu merupakan bahasa pertama, karena ibulah yang pertama berkomunikasi, berinteraksi, dan mengajarkan bahasa kepada anak (Wina Sanjaya, 2009: 57). Bahasa kedua anak di Indonesia umumnya adalah bahasa Indonesia dan bahasa asing. Bahasa Indonesia diperoleh anak dalam lingkungan kehidupannya dan dari pendidikan formal di sekolah. Pemerolehan bahasa asing pada umumnya melalui pendidikan informal maupun formal (Suhartono, 2005: 85).

Bahasa anak sekolah dasar dapat dikembangkan melalui tiga jalur pendidikan yaitu, pendidikan informal, non formal, dan formal. Pendidikan informal dapat ditemukan pada homeschooling, Pada ini pengembangan bahasa sangat penting karena masa usia dini merupakan masa peka bagi anak dan bahasa Inggris merupakan bahasa internasional. Akhirakhir ini pemerintah telah mencanangkan pendidikan yang bertaraf internasional mulai dari jenjang pendidikan dasar sampai pendidikan tinggi. Pembelajaran yang disampaikan di sekolah yang bertaraf internasional memakai pengantar bahasa Inggris. Hal ini dilakukan oleh pemerintah sebagai upaya untuk meningkatkan sumber daya manusia yang memiliki kehandalan dalam berbahasa Inggris. Kebijakan Departemen Pendidikan RI Nomor 0487/14/1992 Bab VIII menyatakan bahwa 


\section{SANG PENCERAH}

Volume 4, Nomor 2, Agustus 2018, Hlm. 39-50

Nur Dahniar: Meningkatkan Kosakata Bahasa Inggris ...

Sekolah Dasar dapat menambah mata pelajaran dalam kurikulumnya, dengan syarat pelajaran tersebut tidak bertentangan dengan tujuan Pendidikan Nasional. Kebijakan ini kemudian ditindaklanjuti dengan Surat Keputusan Menteri Pendidikan dan Kebudayaan Nomor 060/U/1993 Tanggal 25 Februari 1993 tentang dimungkinkannya program bahasa Inggris lebih dini sebagai salah satu mata pelajaran muatan lokal di Sekolah Dasar.

Kemampuan yang harus dimiliki oleh siswa Indonesia menurut Depdiknas adalah memahami dan mengungkapkan informasi, pikiran, perasaan, serta mengembangkan ilmu pengetahuan, teknologi, dan budaya dengan menggunakan bahasa Inggris. Alat untuk berkomunikasi dalam rangka mengakses informasi serta alat untuk membina hubungan interpersonal dan bertukar informasi adalah bahasa Inggris. Pemahaman kosakata merupakan salah satu komponen pembelajaran bahasa. Dari hasil pengamatan yang penulis lakukan, pada waktu pembelajaran bahasa Inggris pada anak usia dini, khususnya di Kelompok belajar anak SD di Kelurahan Katobengke, sering mengalami kesulitan dalam penguasaan kosakata bahasa Inggris. Pelafalan bahasa Inggris (pronounciation) belum benar dan perbendaharaan kosakata yang masih minim. Hal ini disebabkan karena bahasa Inggris jarang digunakan dalam kehidupan sehari-hari. Anak menjadi bosan dan kurang termotivasi untuk mengikuti pembelajaran bahasa Inggris. Latar belakang keluarga yang kurang mendukung pembelajaran bahasa Inggris, pendekatan pembelajaran yang kurang menarik, pemilihan bahan ajar bahasa Inggris yang kurang tepat di sekolah serta komunikasi yang kurang hangat antara guru dan siswa. Juga penggunaan media yang kurang variatif dalam pembelajaran bahasa Inggris pada anak usia dini adalah hal-hal yang menyebabkan masih rendahnya kosakata bahasa Inggris pada anak usia dini. Permasalahan-permasalahan yang ada di lapangan perlu dicarikan solusinya. Peneliti berusaha mencoba berbagai teknik, strategi, dan metode untuk meningkatkan penguasaan kosakata bahasa Inggris di kelompok belajar anak SD di Kelurahan Katobengke. Berdasarkan deskripsi di atas, fokus penelitian ini adalah bagaimanakah meningkatkan kosakata bahasa Inggris melalui bermain gambar pada kelompok belajar anak SD di Kelurahan Katobengke?

Penelitian ini bertujuan untuk mengetahui peningkatan kosakata bahasa Inggris melalui bermain gambar pada kelompok belajar anak SD di Kelurahan Katobengke.

\section{Metode Penelitian}

\section{Metode dan Jenis Penelitian}

Metode adalah cara teratur yang digunakan untuk melaksanakan suatu pekerjaan agar tercapai sesuai dengan yang dikehendaki, cara kerja yang bersistem untuk memudahkan pelaksanaan suatu kegiatan guna mencapai tujuan yang ditentukan (Depdikbud, 2007: 741). Metode berasal dari bahasa Yunani "Methodos" yang berarti cara atau jalan yang ditempuh. Sehubungan dengan upaya ilmiah, maka metode menyangkut masalah cara kerja untuk dapat memahami objek yang menjadi sasaran ilmu yang bersangkutan.

Jenis penelitian ini merupakan penelitian tindakan kelas. Pada penelitian ini peneliti bekerjasama dengan guru kelas. Peneliti dan guru kelas bekerjasama dalam merancang suatu tindakan yang akan dilakukan. Penelitian ini memerlukan data. Idrus (2002: 83) memberikan pengertian data adalah segala keterangan (informasi) mengenai segala hal yang berkaitan dengan tujuan penelitian. 


\section{SANG PENCERAH}

Volume 4, Nomor 2, Agustus 2018, Hlm. 39-50

Nur Dahniar: Meningkatkan Kosakata Bahasa Inggris ...

\section{Data dan Sumber Data}

Data yang dipakai dalam penelitian ini adalah data deskriptif kualitatif dan kuantitatif. Data kualitatif merujuk pada data kualitas objek penelitian, yaitu ukuran data berupa non-angka tetapi satuan kualitas (misalnya istimewa, baik, buruk, tinggi, rendah, sedang dan lain-lain). Data kuantitatif merupakan data yang didominasi oleh angka. Data ini memperesentasikan satu ukuran kuantitatif dari objek yang diteliti dalam satuan tertentu (misalnya, panjang, lebar, berat, volume dan lain-lain). Data kuantitatif dalam penelitian ini adalah peningkatan kosakata bahasa Inggris anak.

\section{Teknik Pengumpulan Data}

Data yang diambil disini adalah data tentang kosakata bahasa Inggris pada anak usia dini. Pengambilan data pada penelitian ini dilakukan dengan:

1. Metode Observasi

Observasi merupakan teknik pengumpulan data dengan cara mengamati setiap kejadian yang sedang berlangsung dan mencatatnya dengan alat observasi tentang hal-hal yang akan diamati atau diteliti (Sanjaya, 2009:86). Pengumpulan data melalui observasi dilakukan oleh peneliti dan teman sejawat pada subyek penelitian untuk mendapatkan gambaran secara langsung kegiatan belajar siswa di kelas. Observasi yang dilakukan meliputi observasi tentang proses pembelajaran bahasa Inggris, keaktifan siswa serta penguasaan kosakata bahasa Inggris anak setelah pembelajaran dengan pendekatan bermain gambar.

2. Wawancara dan Diskusi

Wawancara dan diskusi dapat diartikan sebagai teknik mengumpulkan data dengan menggunakan bahasa lisan baik secara tatap muka ataupun melalui saluran media tertentu (Wina Sanjaya, 2009: 96). Wawancara dan diskusi dilakukan setelah dan atas dasar hasil pengamatan di kelas maupun kajian dokumen. Wawancara dan diskusi dengan teman sejawat dilaksanakan setelah melakukan pengamatan pertama terhadap kegiatan pembelajaran, yang dimaksud untuk memperoleh informasi tentang berbagai hal yang berkaitan dengan pelaksanaan pembelajaran kosakata bahasa Inggris anak usia dini. Dari wawancara pengamatan dan kajian dokumen yang telah dilakukan diidentifikasi permasalahan-permasalahan yang ada berkenaan dengan pembelajaran kosakata bahasa Inggris anak usia dini.

\section{Metode Dokumentasi}

Dokumentasi adalah instrumen untuk mengumpulkan data tentang peristiwa atau kejadian-kejadian masa lalu yang telah didokumentasikan (Mulyasa, 2009: 69). Dokumentasi dilakukan untuk memperoleh atau mengetahui sesuatu dengan buku- buku atau arsip yang berhubungan dengan yang diteliti. Dokumentasi digunakan untuk memperoleh data sekolah dan nama siswa Kelompok belajar anak SD di Kelurahan Katobengke. Dokumentasi juga berupa foto tindakan penelitian, yaitu rekaman proses pembelajaran kosakata bahasa Inggris dengan pendekatan bermain gambar.

Penelitian ini menggunakan triangulasi penyelidikan dengan jalan memanfaatkan peneliti atau penguatan untuk pengecekan kembali derajat kepercayaan data antara guru kelas Kelompok B1, kepala sekolah, dan rekan sejawat yang berdiskusi setelah pengumpulan data agar kesimpulan yang diambil lebih valid.

\section{Teknik Analisis Data}

Analisis data merupakan teknik yang digunakan menganalisis data hasil penelitian untuk membuktikan hipotesis 


\section{SANG PENCERAH}

Volume 4, Nomor 2, Agustus 2018, Hlm. 39-50

Nur Dahniar: Meningkatkan Kosakata Bahasa Inggris ...

yang telah dirumuskan (Suuharsimi, 2007: 104). Pada Penelitian Tindakan Kelas ini digunakan analisis berdasarkan hasil observasi kegiatan pembelajaran maupun dari hasil tindakan yang telah dilakukan. Analisis data dari hasil observasi terhadap guru sebagai pelaksana kegiatan pembelajaran digunakan untuk melakukan refleksi, agar peneliti dapat menentukan tindakan yang dapat diambil pada siklus berikutnya. Analisis data terhadap anak dilakukan beberapa tahap sebagai berikut (Mulyasa, 2009: 101)

1. Menjumlahkan skor yang dicapai anak pada setiap butir amatan.

2. Membuat tabulasi skor observasi peningkatan kosakata bahasa Inggris melalui bermain gambar yang terdiri nomor, nama anak, nomor butir amatan dan jumlah skor. Tabulasi skor dapat dilihat pada Tabel 3 sebagai berikut:

3. Menghitung persentase peningkatan kosakata bahasa Inggris anak melalui bermain gambar, dengan cara sebagai berikut:
a. Persentase pencapaian kemampuan
b. Skor maksimum = Skor maksimum butir amatan $x$ jumlah butir amatan.
c. Skor maksimum $=4 \times 10=40$
d. Hasil persentase diisikan pada Tabel tabulasi pada kolom (\%).

4. Membandingkan hasil persentase pencapaian pada setiap anak dengan persentase keberhasilan pada setiap Siklus yang telah ditentukan peneliti.

Penelitian pada setiap Siklus akan berhasil jika anak sudah mencapai persentase yang telah ditentukan pada setiap siklusnya. Adapun hasil perbandingan tersebut dapat dilihat pada Tabel 3 berikut:
Tabel 3. Lembar Perbandingan Hasil Persentase Pencapian Setiap Anak Dengan Persentase Keberhasilan

\begin{tabular}{cccc}
\hline Nama & Persentase & $\begin{array}{c}\text { Persentase } \\
\text { keberhasilan }\end{array}$ & $\begin{array}{c}\text { Status } \\
\text { pencapaian }\end{array}$
\end{tabular}

Keterangan:

a. Persentase pencapaian: diperoleh dari perhitungan persentase peningkatan kosakata bahasa Inggris melalui bermain gambar pada masingmasing anak.

b. Persentase keberhasilan: diperoleh dari presentase minimal yang harus dicapai anak pada setiap siklusnya.

c. Status pencapaian: diperoleh dari perbandingan antara skor maksimum setiap siklus dan persentase pencapaian setiap anak, dengan ketentuan sebagai berikut: (1) S: Sudah mencapai, jika hasil persentase pencapaian $\geq$ persentase keberhasilan; dan (2) B: Belum mencapai, jika hasil persentase pencapaian $\leq$ persentase keberhasilan.

\section{Pembahasan}

\section{Deskripsi Data Hasil Penelitian \\ Siklus I}

a. Perencanaan Tindakan

Kegiatan yang akan dilakukan pada Siklus I. Hal-hal yang didiskusikan antara lain; (1) peneliti menyamakan persepsi dengan sejawat mengenai penelitian yang akan dilakukan, (2) peneliti mengusulkan pembelajaran bahasa Inggris melalui bermain gambar, (3) peneliti mengusulkan perencanaan pembelajaran berupa RBP (Rencana Bidang Pengembangan) dan sejawat menyetujui, (4) peneliti mengusulkan 


\section{SANG PENCERAH}

Volume 4, Nomor 2, Agustus 2018, Hlm. 39-50

\section{Nur Dahniar: Meningkatkan Kosakata Bahasa Inggris ...}

observasi sebagai instrumen penilaian peningkatan kosakata bahasa Inggris dan (5) menentukan jadwal pelaksanaan tindakan. Pada waktu diskusi disepakati bahwa peneliti sebagai pelaksana tindakan dan teman sejawat sebagai observer. Alokasi waktu di setiap pertemuan selama 30 menit. Adapun tindakan pada Siklus I akan dilaksanakan sebanyak 3 pertemuan.

Beberapa hal yang perlu dipersiapkan pada Siklus I, yaitu: (1) Peneliti mempersiapkan terlebih dahulu media yang akan digunakan untuk pembelajaran bahasa Inggris yaitu gambar-gambar yang didownload dari internet lalu dikemas dan dirapikan sebagai alat peraga, dan selanjutnya peneliti membuat kartu gambar untuk permainan "Lomba mengambil"; (2) Peneliti membuka pembelajaran dengan salam, doa, dan menyanyikan lagu "Assalamualaikum"; (3) Peneliti mengkomunikasikan aturan permainan pada anak-anak tentang kegiatan bermain mengambil gambar di halaman sekolah; (4) Peneliti memberikan apersepsi tentang macam-macam buahbuahan; (5) Peneliti memperlihatkan gambar satu per satu sambil mengucapkan kosakatanya dalam bahasa Inggris; (6) Peneliti meminta anak untuk menirukan kosakata bahasa Inggris yang diucapkan guru sambil menunjukkan gambarnya; dan (7) Peneliti membagi anak dalam empat kelompok dan setiap kelompok ditempatkan di depan lajur yang sudah disiapkan sebelumnya. Empat orang anak disuruh lomba mengambil gambar sesuai perintah peneliti dengan bahasa Inggris "orange". Anak yang sudah mendapatkan gambar tersebut segera menunjukkan ke atas sambil mengucapkannya dengan kosakata bahasa Inggris "orange". Anak yang betul mengambil gambar dan mengucapkannya dengan tepat diberi pujian "good job" sementara anak yang masih salah dimotivasi "no, tray again". Dalam kegiatan ini peneliti dan sejawat mengamati anak yang betul mengucapkan kosakatanya dalam bahasa Inggris, kemudian mencatatnya dalam lembar observasi yang sudah disiapkan; (8) Kegiatan penutup berupa review/mengulang lagi kosakata yang telah dipelajari; dan (9) Peneliti menutup pembelajaran dengan bernyanyi "see you later", berdoa setelah melakukan kegiatan kemudian salam.

Secara umum proses pembelajaran pada Siklus I seperti yang tersebut di atas, akan tetapi pada setiap pertemuan peneliti mengganti kosakata yang lain agar jumlah kosakata bahasa Inggris anak bertambah. Adapun variasi pada setiap pertemuan adalah sebagai berikut:

1) Pada Pertemuan Pertama Siklus I peneliti memperkenalkan lima gambar buah- buahan. Lima gambar tersebut adalah apple, banana, mango, orange dan grape.

2) Pertemuan Kedua Siklus I kegiatan sama dengan pertemuan pertama, hanya saja peneliti memberikan variasi pada gambar buah yang lain yaitu watermelon, avocado, starfruit, jackfruit, dan pineapple. Hal ini dimaksudkan untuk menambah kosakata bahasa Inggris anak.

3) Pada Pertemuan Ketiga Siklus I kegiatan divariasikan dengan bentuk permainan pesan berantai dengan lima kosakata sayur-sayuran.

\section{b. Pelaksanaan Tindakan}

Kegiatan awal dibuka dengan salam dan dilanjutkan membaca doa sebelum belajar kemudian anak diajak menyanyi lagu "the best". Peneliti menjelaskan bahwa kegiatan belajar bahasa Inggris akan dilakukan dengan 


\section{SANG PENCERAH}

Volume 4, Nomor 2, Agustus 2018, Hlm. 39-50

\section{Nur Dahniar: Meningkatkan Kosakata Bahasa Inggris ...}

bermain gambar. Peneliti menunjukkan gambar buah-buahan yang ada tulisan bahasa Inggrisnya. Peneliti menunjukkan gambar satu per satu sambil menyebutkan dalam bahasa Inggris. Anak disuruh menirukan beberapa kali sampai lima gambar yang ditunjukkan oleh peneliti. Anak lalu di suruh berlomba lari sambil mengambil gambar buah yang sudah disiapkan peneliti. Bagi anak yang sudah sampai garis finis lalu anak menunjukkan gambar yang diambil dan menyebutkan kosakatanya sesuai perintah guru.

Peneliti : Sebelum kita mulai belajarnya, kita berdoa dulu ya. Yuk tangan dilipat yang rapi dan seterusnya. Let's start our lesson by saying basmallah (mari kita mulai belajar hari ini dengan bacaan basmallah).

Pada akhir pembelajaran peneliti melakukan review, mengajukan pertanyaan kelima kosakata tersebut dan anak yang betul menjawabnya dengan tunjuk jari. Dalam proses pembelajaran tersebut peneliti dan teman sejawat melakukan observasi tentang anak-anak yang bisa menguasai bahasa Inggris dan benar pengucapannya, kemudian dicatat pada lembar observasi. Paparan tersebut di atas merupakan proses pembelajaran pada Siklus I Pertemuan Pertama. Sebagaimana yang telah direncanakan, secara garis besar proses pembelajaran seperti yang telah disebutkan di atas. Pada setiap pertemuan peneliti dan teman sejawat sepakat untuk memberikan variasi agar anak-anak tidak merasa bosan dan suasana kelas lebih menyenangkan. Pada Siklus I Pertemuan kedua, dilaksanakan pada hari Rabu tanggal 20 juni 2018, peneliti mencoba memvariasikan dengan kegiatan bermain lomba mengambil gambar namun gambarnya diganti jenisnya. Pada pertemuan sebelumnya buah apel, jeruk, mangga, semangka, pisang kemudian di tambah anggur, alpukat, blimbing, nanas, nangka. Sehingga kosakata bertambah menjadi 10 kosakata, kemudian anak diberi pertanyaan dan anak menjawab dengan satu per satu. Untuk menambah motivasi.

\section{c. Observasi}

Observasi dilakukan pada saat pembelajaran. Observasi digunakan untuk mengetahui penguasaan bahasa Inggris, semangat, keaktifan, minat, dan motivasi anak didik dalam mengikuti pembelajaran bahasa Inggris melalui bermain gambar. Dalam kegiatan ini peneliti dibantu oleh kolaborator yaitu teman sejawat. Observasi ini berpedoman pada pedoman observasi yang berbentuk checklist.

Berdasarkan pengamatan yang dilakukan peneliti dan teman sejawat diperoleh data sebagai berikut: (1) Sebagian besar anak tertarik dan antusias mengikuti kegiatan bermain lomba mengambil gambar, (2) Ada beberapa anak yang mengikuti pembelajaran namun terlebih dahulu harus dimotivasi guru karena anak ingin diperhatikan, (3) Waktu Pertemuan Pertama dan Kedua masih kurang karena anak senang dan ingin bermain lagi, (4) Hasil observasi penguasaan kosakata bahasa Inggris anak telah menunjukkan peningkatan yaitu dari tahap pra tindakan 50,52 \%, pada Siklus I mencapai $62,63 \%$, dan (5) Hasil observasi penguasaan bahasa Inggris anak juga menunjukkan bahwa ada empat anak yang mendapatkan nilai tinggi, sedangkan poin terendah ada satu anak. 


\section{SANG PENCERAH}

Volume 4, Nomor 2, Agustus 2018, Hlm. 39-50

Nur Dahniar: Meningkatkan Kosakata Bahasa Inggris ...

\section{d. Analisis dan Refleksi}

Berdasarkan hasil observasi tersebut, peneliti dan teman sejawat melakukan analisis terhadap proses pembelajaran dan penguasaan bahasa Inggris anak. Analisis ini dilakukan oleh peneliti dan sejawat dengan cara berdiskusi, mengevaluasi pembelajaran yang telah dilalui, serta melihat kekurangan-kekurangan yang ada. Selain itu guru dan teman sejawat juga berpedoman pada hasil observasi penguasaan bahasa Inggris anak melalui pedoman observasi..

Hasil analisis tersebut menunjukkan bahwa: (1) Sebagian besar anak tertarik, antusias, dan bersemangat mengikuti kegiatan bermain gambar, hal ini sesuai dengan teori para ahli bahwa dunia anak adalah dunia bermain, (2) Guru kurang dapat membagi perhatiannya pada anak karena terdapat anak yang terus meminta perhatian, (3) Kurangnya waktu pada saat lomba mengambil gambar, ini menunjukkan anak senang dengan kegiatan fisik, (4) Sudah ada peningkatan kosakata bahasa Inggris anak jika dibandingkan dengan penguasaan sebelum tindakan, akan tetapi hasil tersebut belum maksimal, ini berarti bahwa peneliti perlu memperbaiki proses pembelajaran, (5) Peningkatan kosakata bahasa Inggris anak didik dalam satu kelas kurang merata, ada anak yang mempunyai kemampuan lebih dan ada anak yang mempunyai kemampuan yang masih rendah, (6) Ada kosakata yang mudah diingat anak dan ada kosakata yang sukar diingat anak. Dari hasil analisis tersebut peneliti dan sejawat merasa bahwa hasil penelitian tersebut belum maksimal. Oleh sebab itu peneliti dan sejawat membuat perencanaan untuk tindakan pada siklus berikutnya.

\section{Siklus II}

\section{a. Perencanaan Tindakan}

Peneliti dan teman sejawat setelah melakukan diskusi, bersepakat melakukan beberapa hal yang sebaiknya dilakukan dalam pembelajaran. Hal-hal tersebut yaitu: (1) peneliti memaksimalkan tindakan yaitu lebih berinteraksi dengan anak didik, memberi motivasi, balikan, dan penguatan, (2) Agar anak tidak bosan, tema dikembangkan lagi menjadi sub tema macam-macam tanaman seperti buah dan sayuran, serta bagian-bagian tanaman. (3) Adanya anak yang kurang memperhatikan pelajaran dan adanya anak yang meminta tugas maka peneliti bermaksud memberikan tugas menghubungkan dan menebalkan tulisan, (4) Waktu bermain kurang sehingga belum semua anak dapat kesempatan untuk bermain gambar jadi peneliti menambah jam pertemuan menjadi 45 menit, (5) Untuk mengatasi kurang meratanya penguasaan bahasa Inggris peneliti berusaha memberi kesempatan bermain yang merata kepada anak (semua anak dilibatkan), peneliti juga memberikan reward kepada anak sesuai dengan kemampuan yang dimilikinya dengan jumlah porsi yang berbeda, dan (6) Ada kosakata yang mudah diingat anak dan ada kosakata yang susah diingat anak, untuk mengatasi kosakata yang susah diingat, kosakata tersebut diulang beberapa kali baik pada saat pembelajaran maupun pada saat review.

Urutan tindakan yang telah direncanakan dan akan diterapkan pada Siklus II adalah sebagai berikut: (1)Peneliti mempersiapkan peralatan dan media pembelajaran; (2) Peneliti mengkondisikan anak agar siap untuk belajar; (3) Peneliti membuka pembelajaran dengan doa dan mengucap 


\section{SANG PENCERAH}

Volume 4, Nomor 2, Agustus 2018, Hlm. 39-50

\section{Nur Dahniar: Meningkatkan Kosakata Bahasa Inggris ...}

salam; (4) Tanya jawab tentang kosakata yang sudah diajarkan pada pertemuan yang lalu; (5) Peneliti memberikan tentang apersepsi; (6) Peneliti menunjukkan gambar macam-macam sayuran dan bagian-bagian tanaman dan mengucapkannya kedalam bahasa Inggris yang tepat; (7) Peneliti memberi kesempatan pada anak untuk mendengarkan lalu menirukan ucapannya; (8) Peneliti mengajak anak bermain lomba mengambil gambar sesuai perintahnya; (9) Pemberian tugas berupa lembar kerja; (10) Pada anakanak mengerjakan lembar tugas satu per satu anak dipanggil untuk mengucapkan kosakata yang sudah diajarkan; (11) Peneliti memberi reward kepada anak; (12) Peneliti mengulang lagi mengucapkan kosakata yang diajarkan pada pertemuan yang lalu dan pertemuan hari ini; dan (13) Peneliti menutup pembelajaran dengan menyanyi lagu "Carrot", berdoa, dan salam.

Secara umum, pembelajaran pada Siklus II seperti tersebut di atas. Sama proses pembelajaran pada Siklus I.

\section{b. Pelaksanaan Tindakan}

$$
\text { Peneliti pada awalnya }
$$

mengkondisikan anak agar siap untuk belajar. Peneliti mengatur tempat duduk anak agar semua anak dapat melihat gambar dengan jelas dan kemampuan anak merata. Peneliti memulai pembelajaran bahasa Inggris dengan salam, berdoa, dan bernyanyi. Sebelum menyampaikan materi peneliti mengulang materi pada pertemuan yang lalu yakni tentang "Fruits and vegetables". Setelah mengulas kosakata tentang vegetables, peneliti memberikan apersepsi tentang bagian-bagian tanaman. Adapun gambaran dialog antara peneliti dengan anak adalah sebagai berikut:
Peneliti : Assalamu'alaikum wr.wb, good morning every body and how are you?

Anak-anak: Wa'alaikum salam wr wb, just fine.....

Peneliti : Masih ingat tidak gambar buah dan sayur yang kemarin diajarkan Bu guru?

Anak-anak: Masih bu....

Peneliti : Ok. Hebat. Fruit in English? wortel in English? tomat in English?

Anak-anak : Carrot, tomato dan seterusnya ....

Peneliti : Wah hebat sekali, hari ini kita akan belajar masih tentang sayuran.

Anak-anak: Buncis, bayam, terong dan seterusnya ....

Peneliti : Sayuran bahasa Inggrisnya apa ya? Yuk kita lihat di gambar dan tirukan. Sayuran in English Vegetables, kentang in English potato dan seterusnya .....

Anak-anak: Vegetables, potato, carrot etc....

Setelah peneliti memulai pembelajaran dan memberikan apersepsi, peneliti menunjukkan gambar sayuran dan mengucapkannya dalam bahasa Inggris dengan sub tema "Vegetables". Peneliti menyuruh anak memperhatikan gambar lalu menirukan ucapan guru berulangulang, satu kosakata minimal diulang sebanyak tiga kali dan anak-anak menirukannya.

Peneliti : Anak-anak tadi kita sudah melihat gambar sayuran, apa saja tadi sayuran yang ada?

Anak-anak: wortel, kentang, mentimun, dan seterusnya ....

Peneliti : Ok. Wortel in English, kentang in English, Mentimun in English etc...

Anak-anak: Carrot, potato, cucumber etc....

Peneliti : Hebat semua anak-anak. Sekarang anak-anak mau 


\section{SANG PENCERAH}

Volume 4, Nomor 2, Agustus 2018, Hlm. 39-50

Nur Dahniar: Meningkatkan Kosakata Bahasa Inggris ...

$\begin{aligned} & \text { diajak lomba berlari } \\ \text { Pengambil gambar. } & \\ & \text { : } \\ & \text { Bagus, karena anak-anak } \\ & \text { sudah bisa menirukan } \\ & \text { saatnya kita bermain lomba } \\ & \text { mengambil gambar. Kita } \\ & \text { buat empat kelompok ya. }\end{aligned}$

Anak-anak : Ya bu, aku ..aku

Peneliti : Untuk putaran pertama yang berlomba Cherly, Rama, Angelita, dan Aqni. Put the picture potato (coba ambil kentang). Ayo...ayo... Adventine Cherly berlari kencang dan dapat, mengambil dan menunjukkan gambar lalu menyebutkan "potato" dengan lantang.

Peneliti : "Good job" bagus Cherly! Come on Rama kamu pasti bisa.

Setelah anak-anak diajak bermain lomba mengambil gambar lalu anak diberi tugas menebalkan tulisan dengan bahasa Inggris yang sesuai dengan gambar pada lembar kerja anak. Pada akhir pembelajaran peneliti melakukan review, mengajukan pertanyaan kelima kosakata tersebut dan anak yang bisa menjawab diminta untuk tunjuk jari. Dalam proses tersebut peneliti dan teman sejawat melakukan observasi tentang anak- anak yang bisa menguasai bahasa Inggris dan benar pengucapannya, kemudian dicatat pada lembar observasi yang sudah disiapkan berbentuk checklist.

Paparan tersebut di atas merupakan proses pembelajaran pada Siklus II Pertemuan Pertama. Sebagaimana yang telah direncanakan, secara garis besar proses pembelajaran seperti yang telah disebutkan di atas. Namun demikian pada Pertemuan Kedua dilakukan variasi yakni kosakata yang diajarkan berupa bagian- bagian tanaman. Selain itu pada Pertemuan Kedua diberi kegiatan yang berupa menghubungkan gambar dengan tulisan bahasa Inggris yang benar. Variasi juga dilakukan dengan menambah lagu-lagu yang berhubungan.

\section{c. Observasi}

Kegiatan observasi dilakukan pada saat pembelajaran. Observasi digunakan untuk mengetahui penguasaan bahasa Inggris, semangat, keaktifan, minat dan motivasi anak didik dalam mengikuti pembelajaran bahasa Inggris melalui bermain gambar. Dalam kegiatan ini peneliti dibantu oleh kolaborator yaitu teman sejawat. Observasi ini berpedoman pada pedoman observasi yang berbentuk checklist.

Berdasarkan pengamatan yang dilakukan peneliti dan teman sejawat diperoleh data sebagai berikut: (1) Sebagian besar anak tertarik dan antusias mengikuti kegiatan bermain lomba mengambil gambar, (2) Ada beberapa anak yang mengikuti pembelajaran namun harus dimotivasi guru terlebih dahulu karena anak ingin diperhatikan, (3) Pertemuan Pertama dan Kedua pelaksanaan masih kurang karena anak senang dan ingin bermain lagi, (4) Hasil observasi penguasaan kosakata bahasa Inggris anak sudah cukup menunjukkan peningkatan yaitu dari Siklus I 62,63 \%, pada Siklus II ini mencapai 77,5\%. Hasil observasi penguasaan bahasa Inggris anak juga menunjukkan bahwa ada 4 anak yang mendapatkan nilai tinggi, sedangkan nilai terendah ada satu anak.

\section{d. Analisis dan Refleksi}

Proses tindakan pada Siklus II berjalan dengan baik. Kelemahan yang ada Siklus I dapat teratasi walaupun belum maksimal. Hal ini membuat kualitas pembelajaran bahasa Inggris meningkat. Peningkatan kualitas pembelajaran dapat terlihat dari tercapainya indikator yang ditetapkan yaitu tampak peningkatan penguasaan 


\section{SANG PENCERAH}

Volume 4, Nomor 2, Agustus 2018, Hlm. 39-50

\section{Nur Dahniar: Meningkatkan Kosakata Bahasa Inggris ...}

kosakata bahasa Inggris anak dari Siklus I dan Siklus II. Berdasarkan analisis yang dilakukan oleh peneliti, hal ini dipengaruhi oleh permainan yang diterapkan dalam pembelajaran bahasa Inggris yakni melalui bermain gambar. Bermain gambar merupakan strategi pembelajaran yang tepat untuk anak usia dini, karena dengan bermain anak mudah menyerap pelajaran, dengan suasana yang menyenangkan sehingga anak aktif terlibat dalam pembelajaran.

Melalui bermain gambar pembelajaran bahasa Inggris mudah diserap oleh otak anak dan peningkatan kosakata anak juga baik. Hal ini sesuai dengan pendapat Vygotsky (dalam Tadkiroatun Musfiroh, 2005: 14) yang menyatakan bahwa anak perlu bermain karena dalam bermain itulah anak pertama kali menemukan pengetahuan di dalam dunia sosialnya yang kemudian menjadi bagian dari anakanak berpikir dan menyelesaikan masalah. Pada saat bermain itulah anak menunjukkan kemampuan di atas kemampuan yang ditunjukkannya sehari-hari bahwa dirinya adalah seseorang yang sedang diperankannya. Bermain mendorong anak-anak untuk melakukan proses berpikir fleksibel dan proses penyelesaian masalah yang kreatif. Karena anak memfokuskan diri dalam proses bermain, mereka berperan aktif mengkombinasikan ideide dan solusi yang mereka gunakan untuk memecahkan masalah-masalah yang sesuai. Anak-anak mengkonstruksi pengetahuan, mengkaitkannya dengan kontek sosial, dan menggunakan keterampilannya untuk memecahkan masalah.

Selain dipengaruhi strategi bermain gambar, keberhasilan pembelajaran bahasa Inggris ini juga dipengaruhi oleh metode pendukung yang berupa pemberian tugas. Metode pendukung ini juga berperan cukup banyak karena melalui metode ini dapat meminimalkan permasalahan dan kejenuhan yang dialami oleh anak. Metode pemberian tugas ini dapat membantu anak untuk lebih mudah menginterpretasikan pengetahuan yang ia dapat ke dalam memori otaknya. Adapun peningkatan di setiap siklus tidak menunjukkan kestabilan. Di mana presentase peningkatan sebelum tindakan sampai dengan Siklus I mencapai 12,11\%. Dari Siklus I sampai Siklus II mencapai $14,87 \%$. Di sini diketahui bahwa sebelum tindakan sampai dengan siklus II mengalami peningkatan yang cukup signifikan. Hal ini disebabkan karena pada awal-awal pertemuan ketertarikan anak masih sangat tinggi, mereka sangat semangat dan antusias terhadap hal baru yang belum pernah ia dapatkan. Di samping itu bermain merupakan metode yang tepat diterapkan dalam pembelajaran pada anak usia dini, hal ini sesuai dengan prinsip bermain sambil belajar dan belajar seraya bermain.

\section{Simpulan}

Simpulan penelitian ini bahwa penggunaan strategi bermain gambar merupakan strategi pembelajaran yang efektif untuk pembelajaran kosakata bahasa Inggris Anak Usia Dini. Hal ini karena bermain gambar merupakan strategi pembelajaran yang sesuai dengan prinsip pembelajaran pada anak usia dini yakni bermain sambil belajar dan belajar seraya bermain. Melalui bermain anak membangun pengetahuannya, dapat berinteraksi sosial dengan temannya, bebas tanpa beban dan anak merasa senang, hal ini mendorong anak ikut aktif dalam 


\section{SANG PENCERAH}

Volume 4, Nomor 2, Agustus 2018, Hlm. 39-50

\section{Nur Dahniar: Meningkatkan Kosakata Bahasa Inggris ...}

pembelajaran sehingga dapat meningkatkan kosakata bahasa Inggris anak usia dini.

\section{Daftar Pustaka}

Aisyah, Siti Aminah. 2008. Perkembangan dan Konsep Dasar Pengembangan Anak Usia Dini. Jakarta: Universitas Terbuka.

Gambar 2011. Penggunaan Media
Penguasaan Kosakata Bahasa Inggris
$\begin{aligned} & \text { Anak. Skripsi. UMS. (Tidak } \\ & \text { diterbitkan). }\end{aligned}$

Arikunto, Suharsimi. 2007. Penelitian Tindakan Kelas. Jakarta: Bumi Aksara.

Asrini, Sri. 2011. Pengenalan Kosakata Bahasa Inggris Anak Usia Dini Melalui Nyanyian. Skripsi. (Tidak diterbitkan).

Depdikbud. 2007. Kamus Besar Bahasa Indonesia. Jakarta: PT Gramedia Pustaka Utama.

Faila Shafa, Mila. 2010. Pemanfatan Media Audio Visual Sebagai Upaya untuk Meningkatkan penguasaan Bahasa Inggris Anak Usia Dini. Skripsi Surakarta. (Tidak diterbitkan).

Haq, Saiful. 2008. Jurus-Jurus Menggambar dan Mewarnai dari Nol. Yogyakarta: Mitra Barokah Abadi Press.

Idrus, Muhammad. 2002. Metode Penelitian Ilmu-Ilmu Sosial. Yogyakarta: UII Press.

Kasihani. 2008. English for Young Leaners. Jakarta: Bumi Aksara.

Linse, C. T. 2005. Practical English Language Teaching Young Leaners. New York: MC. Graw- Hill Companies, Inc.
Lishbeth H Yteberg. 2004. Teaching English to Children. New York: Longman.

Moleong, Lexy J. 2009. Metodologi Penelitian Kualitatif. Bandung: Remaja Rosdakarya.

Mulyasa. 2009. Praktik Penelitian Tindakan Kelas. Bandung: PT Remaja Rosdakarya.

Musfiroh, Tadzkiroatun. 2008. Memilih, Menyusun dan Menyajikan Cerita untuk Anak Usia Dini. Yogyakarta: Tiara Wacana.

Purboyo, Kunto. 2004. Kak Seto Bermain Dan Kreativitas Upaya Mengembangkan Kreativitas Anak Melalui Kegiatan Bermain. Jakarta: Papas Sinar Sinanti.

Sanjaya, Wina. 2009. Penelitian Tindakan Kelas. Jakarta: Kencana Prenada Media Group.

Slamet Suyanto. 2005. Konsep Dasar Pendidikan Anak Usia Dini. Jakarta: Dinas Pendidikan Nasional.

Suhartono. 2005. Pengembangan Ketrampilan Bicara Anak Usia Dini. Jakarta: Diknas.

Suyanto, Kasihani. 2008. English for Young Leaners. Jakarta: Bumi Aksara. 